\title{
Breathscapes: Natural Environments in Eighteenth-Century Physiology and Psychosomatics of Breathing
}

\author{
Rina Knoeff
}

The common air, that element in which we live, that invisible fluid which surrounds the whole earth $[\ldots]$ never engaged so much the attention of the learned as it has of late years. This fluid, diffused everywhere, the breath of life, deserves so much the more attention and investigation of philosophers, as it is the only substance without which we can scarce subsist alive a single moment, and whose good or bad qualities have the greatest influence upon our constitution. ${ }^{1}$

Thus begins the preface of Experiments upon vegetables, discovering their great power of purifying the common air in the sun-shine, and of injuring it in the shade and at night (1779), written by Dutch physician Jan Ingenhousz (1730-1799). Building on Stephen Hales' experiments with pneumatic troughs and Joseph Priestley's speculations that plants have the ability to improve rotten air, Ingenhousz (who has been generally forgotten by historians of science) discovered that sunlight is an

R. Knoeff $(\bowtie)$

History Department, University of Groningen, Groningen, The Netherlands

(C) The Author(s) 2021

D. Fuller et al. (eds.), The Life of Breath in Literature, Culture

and Medicine, Palgrave Studies in Literature, Science and Medicine, https://doi.org/10.1007/978-3-030-74443-4_11 
essential ingredient of photosynthesis. ${ }^{2}$ As a result of numerous experiments he argued that during the night plants breathe just like animals and so putrefy the air. In daylight, however, they restore the quality of air again. For this reason, Ingenhousz argued, the excretory ducts of plants and trees are placed at the underside of leaves, so dephlogisticated air (oxygen), which is heavier than common air, falls downwards 'as a beneficial shower for the use of the animals'. ${ }^{3}$

Following Ingenhousz' experiments (and those of Hales and Priestley), other eighteenth-century physicians also busied themselves with experiments and speculations on photosynthesis. Towards the end of the eighteenth century it was generally agreed that beneficial air rained down during the day, but that the breath of vegetation was extremely damaging at night. This led to a growing (medical) awareness of the (dis)advantages of plants and trees in houses and urban areas. For instance, Ingenhousz carefully considered the benefits of indoor plants and he argued that the practice of keeping orange trees in a room, 'by way of ornament and to keep the air of the room wholesome', could 'contribute somewhat to purify the air', as long as they were placed close to a window where they could profit maximally from daylight. Yet he strongly advised taking out the plants by night as plants 'absolutely tend to foul the air, principally when they are in flower'. ${ }^{4}$ In a similar vein, the Dutch physicians Rudolph Deiman (1743-1808) and Adriaan Paets van Troostwyk (1752-1837) argued that 'plants certainly are very useful in stuffy rooms', which made them wonder how nature, during the winter months, when the trees and lands were bare, improved the air. ${ }^{5}$ Willem van Barneveld (1747-1826) and Joachim Muller (dates unknown), a Utrecht apothecary and an Amsterdam gentleman, concluded after many experiments on different plants that the plant Sedum Telephium (sometimes appropriately known as 'live forever') could restore great quantities of air and was therefore suitable to place at the windows of almshouses, hospitals, and sickrooms. ${ }^{6}$ Ingenhousz' discoveries were soon known throughout Europe and it became generally known that 'the leaves of plants growing in light purify or renovate the air, by supplying it with fresh oxygen'?

With respect to the improvement of air through plants and trees, and the subsequent step to include 'nature' in urban spaces, another important question was how many trees should be planted and what the distance should be between them. It was generally acknowledged that trees were necessary for purifying the air, but on account of their foul breath at night it was said that they should not be placed too close 
to bedroom windows. Against the planting of too many trees, it was also argued that autumn leaves on the streets and in the canals would breathe extra unhealthy vapours. Moreover, the presence of too many trees in narrow streets would hinder the winds necessary for blowing away harmful particles in the air. Not surprisingly, an article in the Dutch journal Vaderlandsche Letteroefeningen in 1810 argued that the Dutch and English had been wrong in planting too many trees in close vicinity to their mansions: it is better, the article stated, 'to plant small forests some distance from the house, they break the strength of the winds, give shadow, lessen humidity and increase the purity of the air'. ${ }^{8}$

Although the photosynthesis experiments of Ingenhousz and his circle have been largely forgotten in the wake of Lavoisier's (chemical) discoveries concerning the role of oxygen and hydrogen in combustion, they were an important part of late eighteenth-century medical thinking about the importance of natural environments and clean air for respiratory physiology. From Antiquity onwards, air, the first of the six Hippocratic non-naturals, referred not only to the air we breathe, but also to the natural environments that produce (breathe) and determine the quality of air. During the 1760s, it was discovered that air was an amalgam of different kinds of air. This led to the revival of an old (Hippocratic) discussion of whether bad air (i.e., bad natural environments) can cause contagious diseases. Moreover, this discussion added to Ingenhousz' earlier notion that plants imbibe and release 'the breath of life'. As a result (natural) environments became an essential part of respiratory theories.

This essay is concerned with the question of how the medicine of respiration is bound up with natural environments, not only in a literal sense, concerned with the quality of air, but also in the layout of parks in urban spaces and the material culture of households, in particular in the design of chimneys and ventilators, as well as in the widespread presence of landscape paintings in living rooms. With respect to the latter, it was thought that the viewing of spacious landscapes would stimulate the imagination and literally give breath. The inclusion of natural environments in medical ideas and advice about breathing was facilitated by a changing focus in eighteenth-century physiologies of respiration. In the wake of new (chemical) theories about the nature of air, experiments in photosynthesis, and speculations concerning oxygen and combustion, the focus of respiratory medicine changed from anatomy and an emphasis on the organs of respiration to the physiology and pathology of breathing as a process that was as much linked to individual organs as it was to 
the mind and (natural) environments. ${ }^{9}$ The effects of this change were considerable. The Scottish physician Robert Menzies argued that 'physicians were, till very lately, totally ignorant of the effects of respiration on the system: Modern chemistry, by discovering the component principles of atmospheric air [...] induced philosophers to examine the subject with the degree of attention it is merited'. ${ }^{10}$ The new focus on respiratory physiology, in short, turned breathing into one of the big topics of eighteenth-century physiology.

\section{Respiration in Eighteenth-Century Medicine}

The changing physiology of respiration can be very well observed in the academic lectures of the famous medical teacher Herman Boerhaave (1668-1738) and the pathology of Jerome Gaub (1705-1780), Boerhaave's pupil and follower in the chairs of medicine and chemistry at Leiden University. ${ }^{11}$ Boerhaave linked breathing to the mechanical motion of the circulation of the blood and emphasized that the quality of breathing is indicative of the health of the underlying organs. Gaub, on the contrary, considered the physiology and pathology of respiration as an autonomous process that was to a certain extent independent of the organs of breathing.

Boerhaave discussed respiration in Book IV of his Academical Lectures 'containing the economy of the external and internal senses, sleep and respiration' and again in Book VI on the 'signs of health'. He argued that 'what respiration is, or how it is performed, and why it continues without the influence of the mind' is difficult to understand. He concluded that it can best be studied by considering the 'infinite number of organs' involved in the process. ${ }^{12}$ In Boerhaave's mechanical teaching, respiration, that is, the inflation and deflation of the lungs and thorax (which also affects the movement of the abdomen), facilitated by the elasticity of air, assists the heart and blood vessels in propelling the blood forward. Boerhaave proved his point with reference to a surgical procedure: when a vein has been opened, if a patient is ordered to cough, the blood 'instantly flies forth in a full stream $[\ldots]$ therefore coughing must evidently accelerate the motion of the blood'. ${ }^{13}$ As a result, Boerhaave's medicine envisioned a relation between the contraction of the heart and the number of breaths. The anatomy of organs, muscles, and bones involved was a key concern. The nature and quality of air were only important in relation to its weight and pressure on the lungs. So Boerhaave argued that light air did not give 
enough pressure, so the resulting constriction of the lungs would suffocate asthmatic patients; moist air was not elastic enough; and cold air was too heavy and squeezed the blood vessels.

In other words, in Boerhaave's system respiration was an important sign (together with the pulse and urine), indicating the (un)healthy functioning of internal organs. He formulated an extensive semiotics related to respiration, arguing that 'there are hardly ten people in a hundred having the same respiration'. A painful respiration denoted an internal inflammation; a small or short respiration signalled that the lungs or windpipe were full of blood or mucus; a quick respiration referred to injured organs of breathing; a suffocating respiration was a sign of inflamed lungs or asthma. By contrast, Boerhaave considered 'an easy, large, slow, equal, and refreshing respiration, performed only by a gentle motion of the intercostal and abdominal muscles, with the diaphragm, the most healthy'. According to Boerhaave even Galen had admitted that no one ever yielded to any disease while manifesting these signs. ${ }^{14}$ In short, for Boerhaave difficult breathing was mainly related to the heart and blood circulation and almost certainly signalled organic trouble. He argued that it 'is therefore one of the worst presages'. Boerhaave nowhere considered respiration as an independent physiological process that depends as much on the condition of organs as it does on passions and emotions and the quality of the surrounding air.

During the second half of the eighteenth century, Boerhaave's ideas on respiration came under attack. Robert Harrington (1751-1837) blandly stated that 'Boerhaave is demonstrably wrong'. ${ }^{15}$ London physician Hugh Smith (d. 1790) rejected Boerhaave's ideas, calling them absurd, and rather than pointing to the organs of respiration, he argued that the noxious effects of impure air infused in the blood were devastating (in particular in the case of pox and other epidemic diseases). ${ }^{16}$ Most criticism was the result of a general shift away from the organs of respiration towards the nature and quality of air in animal and 'vegetable' breathing. As a result, breathing was no longer solely seen as a sign pointing to the 'true' condition of underlying organs. Instead, breathing was increasingly considered a symptom of respiration which could become a distemper itself. ${ }^{17}$

An excellent example of this shift can be observed in the work of Jerome Gaub. His Institutiones pathologiae medicinalis (1758) was widely read throughout Europe. The Edinburgh professor of medicine William Cullen (1710-1790) recommended Gaub's work as 'the best system of 
pathology'. Rudolph Virchow still used Gaub's pathology as a medical student in Berlin in the 1830s and later called it 'the world's first textbook of general pathology and the standard until far into the nineteenth century'. ${ }^{18}$

Gaub placed the symptoms of respiration among the symptoms of the vital motions, together with the symptoms of the heart's motion, the pulsation of the arteries, and the natural functions. He defined a symptom as a 'visible alienation from the natural state, which arises in the body from disease'. It is visible to the senses of both the patient and doctor and should not be confused with the disease itself. The latter is important: Gaub insisted that symptoms 'arise in the body from disease, but in such a manner as to be considered distinct from it. ${ }^{19}$ This means that although symptoms are often caused by the disease, they just as often originate in the cause of the disease or from other symptoms. As a result, Gaub's list of the numerous and various injuries to which respiration is liable is long and diverse, and includes causes as different as the quality of air, troubles with blood, and mental disturbances leading to anxiety. The kinds and degrees of breathing difficulties are even more numerous: 'shortness of breath, asthma, short, creaking, loud, and deep respiration, strangulation \&c. ${ }^{20}$ In addition, Gaub argued that symptoms of breathing are often morbid as well as salutary. Thus coughing and sneezing can be symptoms of a disease, but these violent movements also remove noxious particles from the nose, mouth, and lungs. Morbid laughing is similarly caused by a tickling of the diaphragm, but can be uplifting at the same time; sighing is caused by grief, but eases the anxiety that goes with it; yawning has the salutary purpose of waking up drowsy people.

Additionally, Gaub argued that symptoms might arise from the mind (in particular the power of excitement and the urge to avoid pain) or the 'circumambient air [...] things ingested or applied externally'. ${ }^{21}$ In fact, Gaub considered respiration the most important process mediating between the body's interior and external surroundings. All this means that in Gaub's rational pathology symptoms do not have a one-on-one connection to disease, but instead must be considered individually and to a certain extent as independent from the body and its organs. In viewing respiratory trouble as a symptom, rather than a sign as Boerhaave had done, Gaub signalled that troubled breathing could be considered a medical problem in itself, rather than merely as a sign indicative of an organic problem. Moreover, the idea that breathing has its own dynamics opened up the possibility of including natural environments, the nature 
of air, and the 'government of the mind' in the physiology of respiration. So, in addition to obstructions in the respiratory organs (inflammations, pustules, ulcers, tubercles, congestions of blood, pain, etc.), Gaub included 'the air offending by heat, humidity, gravity, levity, stagnation and corruptions' as well as

celestial bodies, meteors, climates, seasons of the year, diversity of soils, mountains, seas, lakes, marshes, rivers, vegetables, animals, subterraneous caverns, the number of inhabitants of a place, manner of life, aliments, drink, fuel of the fire, employments, arts, commerce, and many other things, [which] all contribute their share. ${ }^{22}$

In other words, surrounding atmospheres were made an integral part of the physiology of respiration and as such were widely discussed in terms of health regimens, medical treatment, and climate control. ${ }^{23}$

As a result, atmospheric health not only stimulated chemico-medical research, but also asked for technological innovations and interventions in natural environments. The building of chimneys and fireplaces was reconsidered as they were thought to be very unhealthy: 'some of them very fatal in their consequences to health' which 'cost the lives of thousands every year in this island' [of Ireland]. ${ }^{24}$ Particularly widespread were Stephen Hales' ventilators which significantly improved the air in enclosed spaces such as prisons, workhouses, ships, hospitals, and mines. ${ }^{25}$ One of the best-known inventions was the eudiometer, an instrument to measure the breathability of air. The instrument dovetailed with worries about climatic susceptibility and the idea that aerial pathologies were indicative of the contemporary moral decline into laxity and effeminacy. As a result, eudiometry became a key element in a general programme of economic and social reform. ${ }^{26}$ Apparently, the British believed they were particularly susceptible to the prevailing dullness and dampness of the air, which had a depressing effect on the spirits of the population. ${ }^{27}$ In the Netherlands, medical writers advocated drying the marshes in order to improve the air and by extension the (moral) character of the Dutch. ${ }^{28}$

Outdoor exercise was similarly promoted as a way to improve breathing. ${ }^{29}$ John Sinclair wrote in his Code of Health and Longevity (1807) that 'the great object of training, is to obtain the benefit of a free respiration'. ${ }^{30}$ As a result he advised regular exercise, which he appropriately labelled the 'breathing hour' of each day. 
A free and powerful respiration is most essential to a fresh colour of the face, to lively spirits, and cheerful feelings and to the healthy and vigorous actions of the body. "It is my breathing hour of the day," says Hamlet to Osric $[\ldots]$ there is little doubt, that if all those who linger away their hours in luxurious and indolent relaxations, were to assign a regular portion of their time, to the hardy and manly exercises of walking, riding, fencing, \&c. and would take their breathing hour, they would breathe long and well. ${ }^{31}$

Walking and horseriding were favoured as exercises par excellence. They literally afforded 'various changes of the air', as well as changes of scenery which 'amuse the mind'. ${ }^{32}$ Asthmatics and consumptives were particularly advised to undertake outdoor exercise in addition to 'talking out loud' in order to improve their breathing. ${ }^{33}$ Exercise was best carried out in the morning, for the morning air 'braces and strengthens the nerves'. In addition, the bad air of towns must be avoided 'like the plague'. ${ }^{34}$

As a result of the increasing emphasis on 'taking the air', health committees and garden theorists advocated public parks in urban spaces 'for the health of rich and poor'. These parks were designed according to the latest theories about the air-improving qualities of vegetation. For instance, with reference to Ingenhousz, the Amsterdam Committee of Medical Supervision decided that trees should be carefully spaced in order that the earth's vapors beneath them would be substantially purified and dispersed in the atmosphere' ${ }^{35}$ Indeed representations of late eighteenth-century parks in Britain and on the Continent all depict people leisurely strolling below carefully spaced trees (Plate 11.1).

The parks provided the beneficial air needed for healthy respiration and by extension the vitality of the body. Not surprisingly, by the beginning of the nineteenth century there were fears that the English Royal Parks-what William Pitt (1708-1778) had allegedly called the 'lungs of London'-were in danger of being gobbled up by a rapid expansion of the surrounding buildings, seriously threatening the health of the population. ${ }^{36}$

By the end of the eighteenth century, 'taking the air' was considered so important that physicians generally warned that bad weather should not detain one from venturing outside. William Cadogan, author of the controversial thesis that most chronic diseases (most notably consumption and gout) are caused by lack of outdoor exercise, argued that in bad weather I can see no great evil in throwing a cloak round his [the 


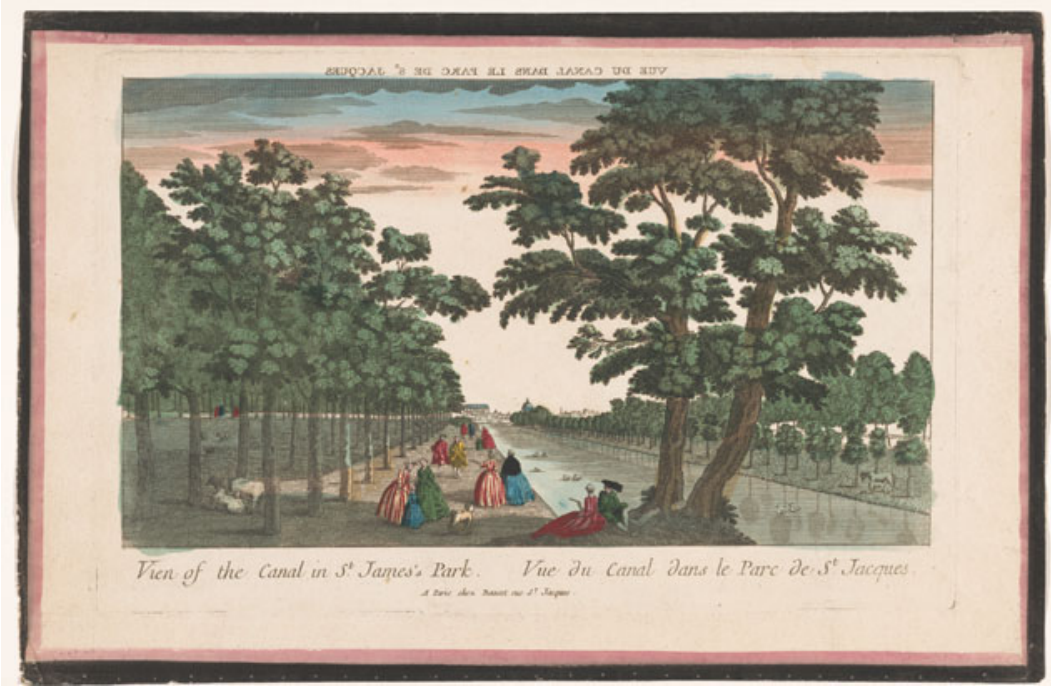

Plate 11.1 View of the Canal in St. James's Park, London. Basset, Paris, 17001799 (Courtesy of the Rijksmuseum Amsterdam)

patient's] shoulders and walking even in the rain; the only difficulty is to summon resolution enough to venture out'. Yet he also admitted, like many physicians in his day, that sometimes people were too weak or it was simply too cold and wet to venture outside. In these cases he advised the use of an indoor exercise machine. ${ }^{37}$ Staying indoors significantly reduced the benefits of 'getting fresh air', but, as I argue below, decorations of idyllic and breathy landscapes in paintings and on wallpaper were meant to stimulate the impression of healthy air and give the viewer the illusion of being outside. The emerging eighteenth-century field of 'psychosomatics' further legitimized the representation of outside air in indoor settings in aid of a better respiration. ${ }^{38}$

\section{The Psychosomatics of Indoor Breathing}

Ever since ancient Hippocratic writings and the medical works of Galen, physicians and natural philosophers have acknowledged that troubled breathing and other bodily discomforts often originate in disturbances 
of the soul. As a result of the eighteenth-century revival of Hippocratic medicine, these concerns were high on the medical agenda again. According to the historian of medicine L. J. Rather, eighteenth-century doctors 'ascribed as much or more in the way of bodily change to the emotions or "power of imagination" than would all but the most convinced proponents of the psychological causation of diseases today'. 39 Consequently, treating the mind as well as the body became a serious medical concern. The French physician Pierre Jean Georges Cabanis (1757-1808) wrote in 1795, 'woe to the medical man, who has not learned to read the human heart as well as to recognize the febrile state', and Gaub argued that 'the careful management of the mind $[\ldots]$ is the concern of everyone and above all that of the physician' ${ }^{40}$ For Gaub, this was most definitely the case with respiratory trouble: 'respiration is indeed subject to the government of the mind, as it performs various functions, which are regulated by the will'. ${ }^{41}$

Respiration in relation to emotional balance was a prominent theme in Gaub's two influential orations on the regimen of the mind. Gaub delivered these orations as Vice Chancellor of Leiden University in 1749 and 1763. At the time they were well known for their clarity and elegance in expressing the 'truly philosophical' notions and principles of mindbody interactions. ${ }^{42}$ Yet although the orations were popular in Gaub's own time, they were quickly forgotten afterwards. In the second oration (1763) Gaub argued that the mind actively partakes in the maintenance of bodily health: 'the mind can variously alter the state of the body, so that absolutely none of the motive powers, functions, interior organs and humors can resist its force'. ${ }^{43} \mathrm{He}$ explicated his argument with a reference to respiration: 'To begin at birth, what is more important to the life of the newborn infant when it first comes to the light and thereafter to man at every stage of growth, than breathing? Do you hold that the body of its own accord initiates breathing? Even though an answer to this question is still lacking, it is more likely the mind'. ${ }^{44}$ When respiration is impaired, leading to anxiety and distress, the mind actively intervenes. For instance, when a man is troubled by respiratory difficulty, the mind strengthens the voluntary muscles and adjusts the position of the body, so that it breathes more easily. ${ }^{45}$ The assistance of the mind in restoring health is often effected through the unconscious mediation of (violent) emotions. Again, Gaub referred to respiration: 
Sighing, by the assistance of the voluntary muscles, draws in the breath very deep, even to the bottom of the breast, and, more forcibly than usual, expels it upwards. Thus nature, by a great and long draught of respiration, increases the beneficial effects of the air, procures refrigeration to the suffocating heat, excitement to the pulmonary circulation, a remedy to difficulty of breathing, and ease to anxiety. ${ }^{46}$

Not surprisingly, Gaub closely linked respiration to anxiety: 'impediments of respiration furnish the most frequent cause of anxiety', and vice versa, through imaginary fear, anger, terror, excessive joy, or lovesickness 'the mind is often thrown into extreme anguish', affecting respiration. Thus, anxiety is 'a monitor of the vital system', and 'even more than pain deserves to be attended to'. ${ }^{47}$ An important way to ease anxiety was through taking exercise, getting fresh air, and contemplating nature outside in landscapes and parks as well as inside through viewing idyllic and pastoral paintings. In fact, eighteenth-century writers on art invoked medical ideas in contemplating the effects of viewing beautiful landscapes on the body's fibres and (blood) vessels.

For instance, the well-known London writer Uvedale Price (17471829) in his Essay on the Picturesque (1796) argued that the viewing of beautiful landscapes alleviated anxiety, calmed the mind, and steadied breathing. In his explanation he referred to contemporary physiological ideas on fibres, the elementary and vital building-blocks of the body, in stating that beauty excites passion and relaxes the fibres. ${ }^{48}$ Although some authors would claim that pleasure stimulates rather than relaxes the fibres, Uvedale conceded that it did not matter: whether stretching or relaxing, the 'active agency [of the picturesque which leads to curiosity] keeps them [the fibres] to their full tone'. ${ }^{49}$ Vice versa, 'wrong' colours or representations could lead to illness. The Dutch physician Lambertus Bicker (1732-1801) reports on a gentleman who always suffered from breathlessness and swooning as soon as he entered a room with blue wallpaper. ${ }^{50}$ Likewise, Diderot's idea that paintings should represent the colours of nature in order not to offend the organs of the body ('the tender and weak eye will never find pleasure in lively and strong colours') was a familiar theme. ${ }^{51}$ Precisely for this reason, it was advised never to decorate bedrooms in white or red, but to follow nature and use green paints and wallpaper. ${ }^{52}$ Speculations about the effect of vision and colours on passions, organs, and fibres dovetailed with Gaub's psychosomatics, as well as with the work of William Cullen and other eighteenth-century 
medical writers who argued that there was a direct connection between 'the energy of the brain' and the fibrous strength of vital organs. ${ }^{53}$

The art historian Frances Gage has similarly argued that landscape paintings in early modern Italian domestic spaces had therapeutic effects:

Landscape painting $[\ldots]$ replicated many of the perceived therapeutic and preservative effects of actual landscape and could function as a substitute for the direct experience of nature [...] through its compositional structures and varied depictions of nature's most desirable properties, landscape painting also promised a more completely healthful experience than did nature herself. ${ }^{54}$

In particular, Italian galleries, placed away from the polluted streets and infused with good air, were meant as places of health and exercise. They were decorated with landscape paintings and gave early modern gentry the sense of outdoor exercise while taking a stroll inside. ${ }^{55}$ Italian doctors were convinced that 'the viewing of beautiful perspectives' improved the experience of breathing good air. Through gazing at such paintings, the beholder would 'follow a visually cathartic process of purification' in moving from bad air in his direct environment to the wholesome air of the painting. ${ }^{56}$ In other words, imagining good air would improve breathing experiences.

During the eighteenth century, landscape painting also boomed in Northern Europe. Artists and physicians began emphasizing the health benefits of their paintings in a similar way. In particular the art of French painter Claude Lorrain (1600-1682) became famous across Europe and was appreciated for the 'calm and dignified repose and harmony of tint', 'the calm beauties of antiques', the 'warmth' they transmitted to the beholder, and the illusion of becoming inhabitants of the mythical Elysium. ${ }^{57}$ From the 1750 s the comforts of landscape painting were widely recommended as they made the viewer imagine himself either hunting, or taking the air, or walking, or sitting, and giving himself up to agreeable meetings' ${ }^{58}$ The well-known English painter Joshua Reynolds (1723-1792) argued that Lorrain's paintings 'lead us to the quiet rest of Arcadian scenery or the country of the fairies' and that 'the purpose of these paintings is to impress the senses and imagination; the imitation of nature often achieves this goal'. ${ }^{59}$ In the Netherlands, it was increasingly important to identify with Dutch landscapes. In order to get the most out of getting fresh air indoors, people had to relate to familiar 
outdoor views. So, while seventeenth-century poet Joost van den Vondel (1587-1679) observed that the arcadic landscape paintings of Herman Zachtleven (1609-1685) allowed one to take the air while conveniently staying at home, from the 1750s this gradually changed to an appreciation for the simple and familiar views of Dutch nature. ${ }^{60}$ This meant the enjoyment of particular Dutch landscapes with low horizons, vast skies, rivers, grassy meadows, and cows: 'though Italy may delight its inhabitants' senses with the splendor of its most beautiful scenery, all the splendid views of a Vesuvius cannot compare to the sight of a rich meadow full of thriving cattle'. ${ }^{61}$

The close connection between medical and artistic ideas shows that paintings - of idyllic landscapes in particular-were considered an important part of the material culture of eighteenth-century households, conducive to the mental and physical health of their residents. This may also explain the revival and popularity of scenic wall decoration during the second half of the eighteenth century. ${ }^{62}$ In Britain and the Netherlands wallpaper manufacturers thrived. From the 1780s newspaper articles advertising cheap or second-hand wallpaper (the latter originating from household effects) doubled. Wallpaper factories not only produced luxurious, expensive wallpaper, primarily depicting naturalistic and idyllic landscapes, made according to the individual tastes of wealthy buyers and printed on linen, but also cheaper wallpaper printed on cotton or paper for a growing market of middle-class homes. ${ }^{63}$ The former was meant for manor houses, townhalls, and theatres (Plate 11.2).

The history of eighteenth-century wallpaper remains to be written, but art historians have recently linked the popularity of floor-to-ceiling 'painted rooms' to the eighteenth-century popularity of natural history and idyllic gardening. They have suggested that 'painted rooms' secured the enjoyment of nature inside the house. In particular during the long and harsh winter months, the 'green tree crowns and a summer atmosphere' would invigorate the weary soul. ${ }^{64}$ The (landscape) painter Arnold Houbraken (1660-1719), in a poem on a painted room in the house of statesman Cornelis Backer in Amsterdam, contrasted the chill of the barren and snowy trees outside with the impression of summer provided by leafy trees inside: 'Here he [the weary statesman] can relax and string his bow again'. ${ }^{65}$ Indeed, although taking the air indoors was a familiar motif in early modern Europe, it flourished during the eighteenth century and kept pace with a mounting appreciation for healthy breathing in relation to natural environments (Plate 11.3). 


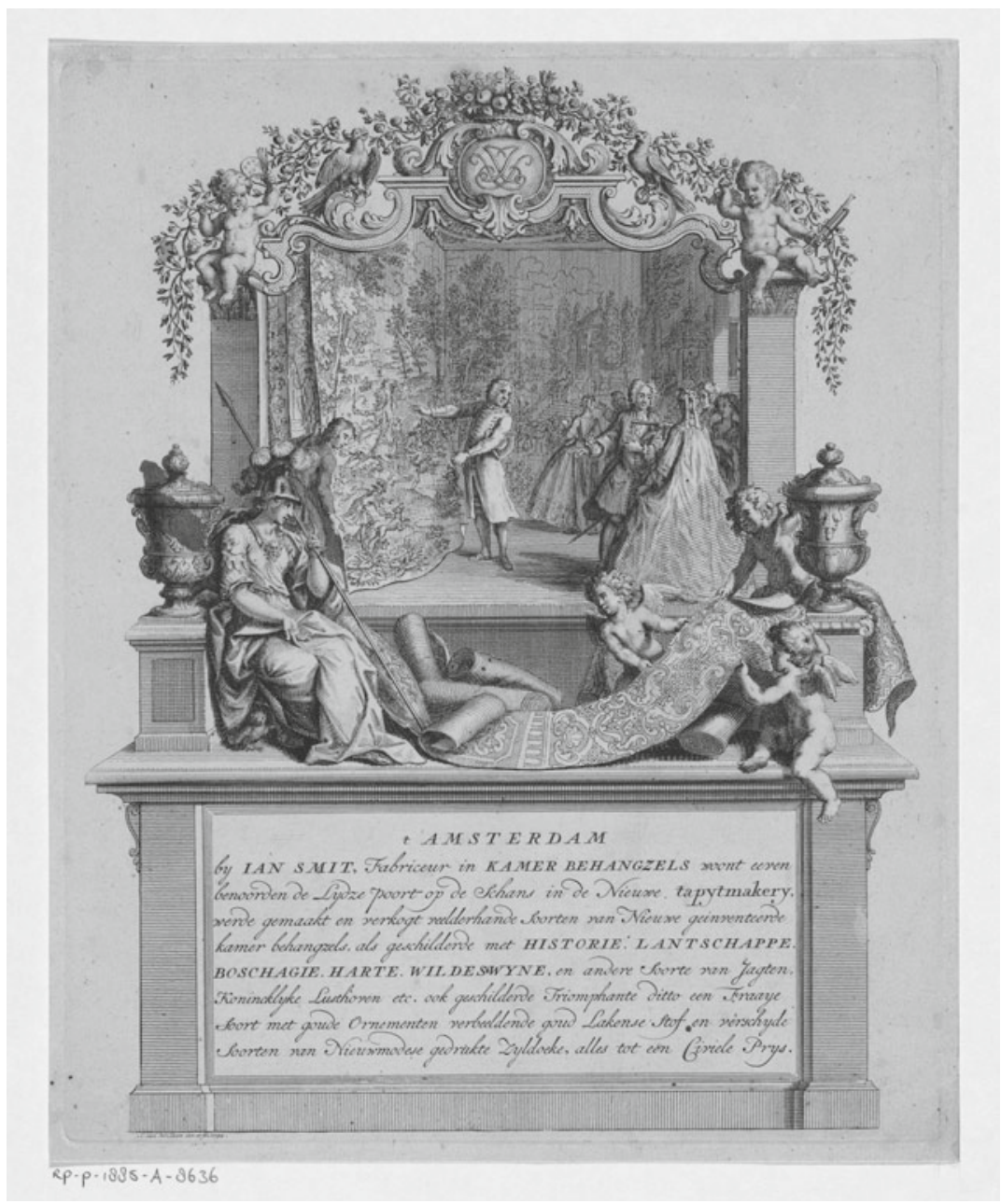

Plate 11.2 Wallpaper advertisement of Jan Smit, wallpaper entrepreneur in Amsterdam. Adolf van der Laan, 1734 (Courtesy of the Rijksmuseum Amsterdam) 


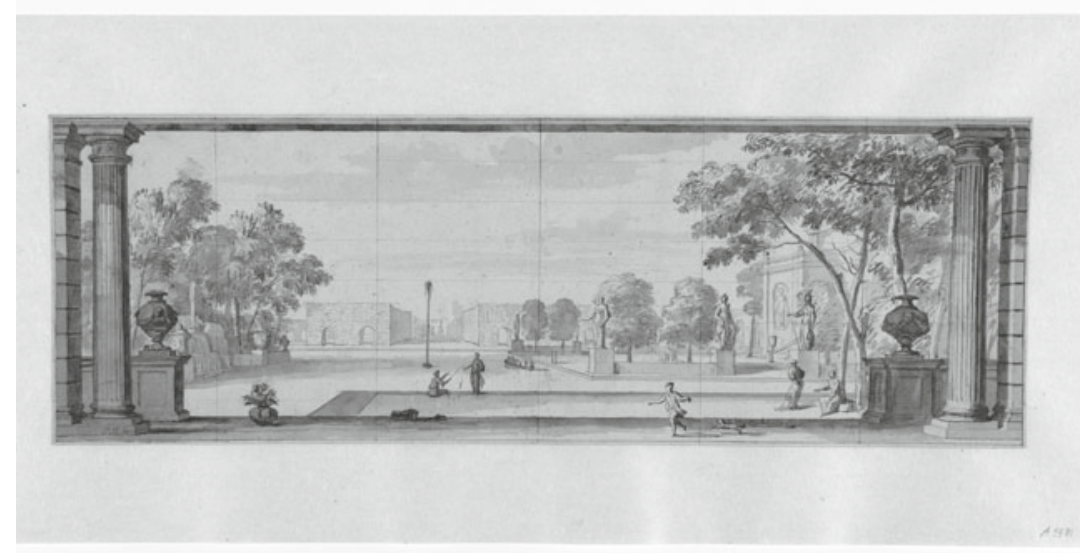

Plate 11.3 Design for wallpaper with a view of a park. Anonymous, 17001800. The viewer would be at the same height as the boy playing with the dog, giving the sensation of being in the park (Courtesy of the Rijksmuseum Amsterdam)

\section{CONCLUSION}

One of the most beautiful painted rooms can be found in the luxurious interior of the doll's house of Petronella Oortman (1656-1716). ${ }^{66}$ The doll's house, which cost as much as a real Amsterdam canal house, was a popular tourist attraction during the eighteenth century. For the purpose of this essay it is particularly interesting to have a closer look at the drawing room or Zaal, which is decorated with floor to ceiling landscape paintings. Significantly, the paintings continue in a painted ceiling with birds flying in a serene and slightly clouded light blue sky. To eighteenthcentury viewers this must have looked familiar. Not only were painted ceilings with clouds and birds a popular motif in early modern art, but also a translucent sky visually represented the most healthful air. ${ }^{67}$ In this case, the impression inside such a room must have been of being outside, the ceiling giving the sensation of being in open air so breathy, pure, and light that the birds simply float on it (Plates 11.4 and 11.5).

In a way the mini-drawing room summarizes the argument of this essay. The healthy air provided by idyllic landscapes-outdoors as well as imagined through paintings and murals-literally gave air and assisted 


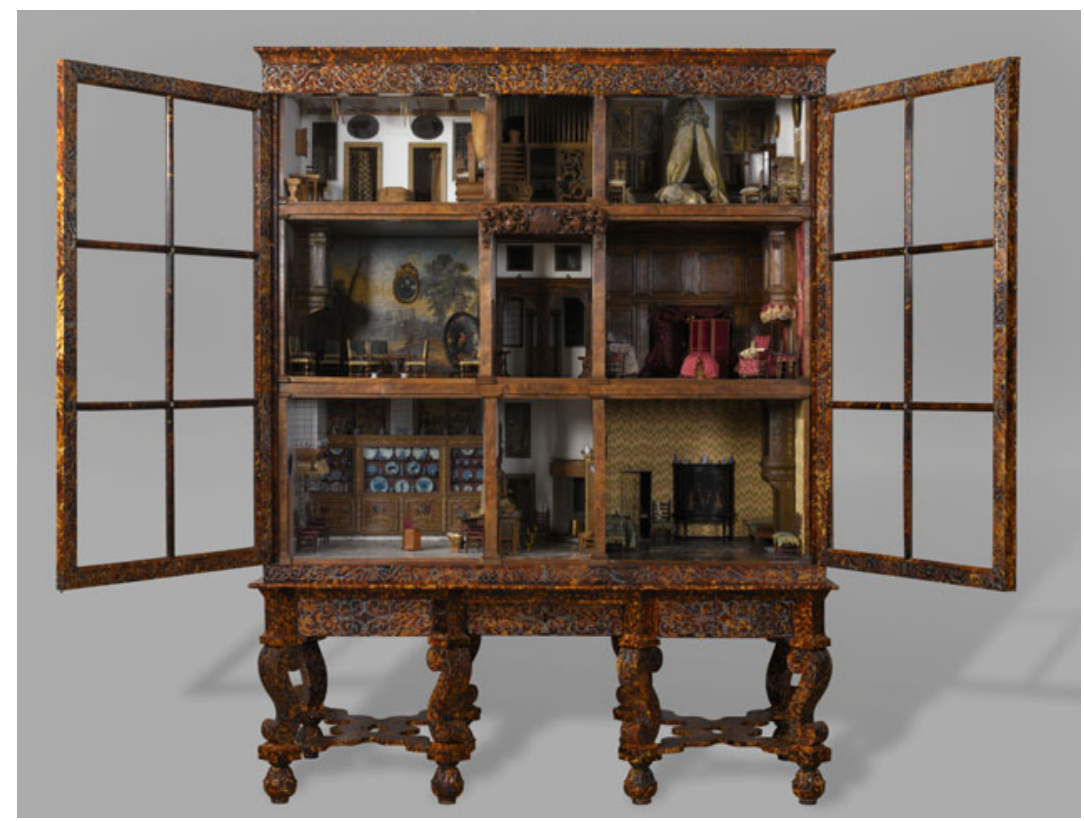

Plate 11.4 Petronella Oortman's doll's house. The drawing room is located on the left side on the second floor. Anonymous, ca. 1686-1710 (Courtesy of the Rijksmuseum Amsterdam)

healthy breathing. Supported by new physiologies of respiration as well as a renewed emphasis on the imagination as a means to relieve anxiety-related breathing trouble, eighteenth-century people quite literally believed that nature breathes as we do. This means that taking a walk in the park, along the trees that exhale and inspire the atmosphere with beneficial air, would surely improve respiration and health. Likewise, as Frances Gage has argued, the viewing of landscapes with airy forms, indistinct contours, and softened colors produced 'a visual analogue to the softening and purifying effects that trees and foliage were understood to exert upon the air and upon the substance of the body in return' ${ }^{68}$ In all cases, breath was an important, yet often invisible, go-between linking body, mind, and environment. So, in Oortman's doll's house, the drawing room's landscapes signify more than pretty paintings meant to divert the eye. They were meant to animate the house, transcending the threshold 


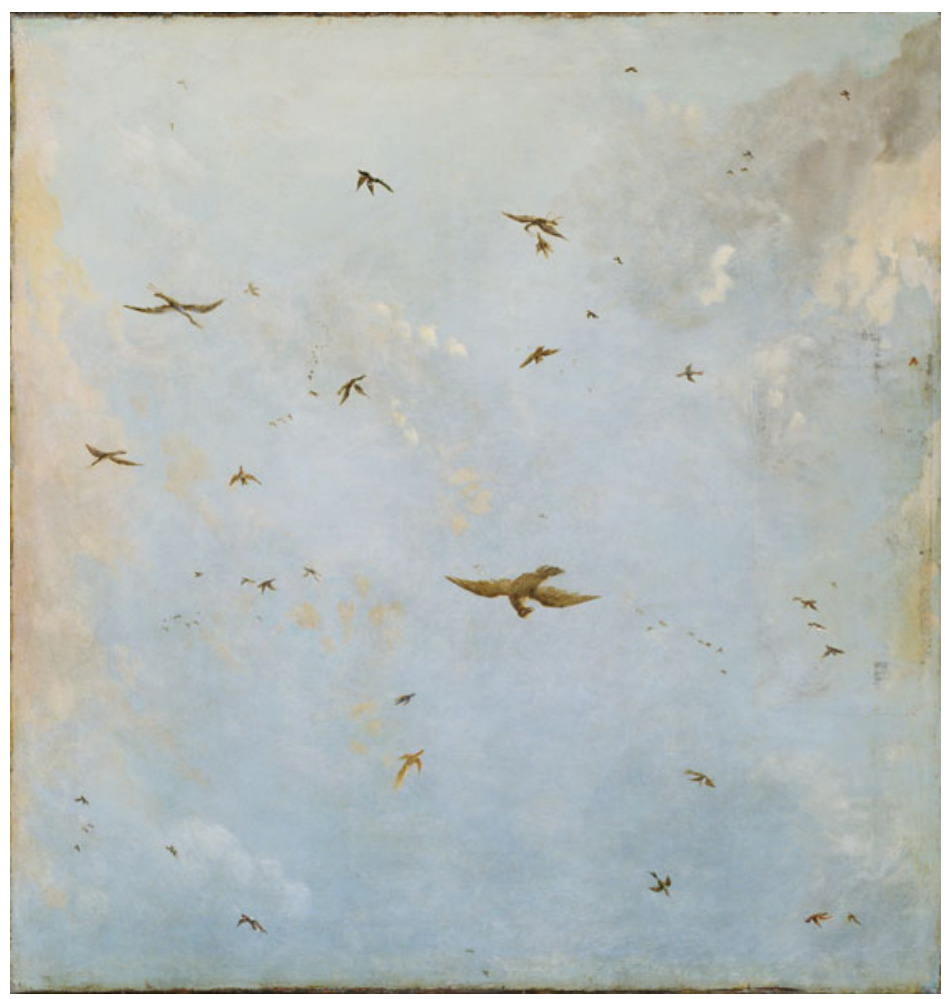

Plate 11.5 Detail of the painted ceiling in Petronella Oortman's doll's house. Attributed to Nicolaes Piemont, ca. 1690-1709 (Courtesy of the Rijksmuseum Amsterdam)

between life and death, giving the viewer the impression of gazing at a household invigorated with the breath of life, perhaps even feeling better for it.

\section{Notes}

1. Jan Ingenhousz, Experiments Upon Vegetables, Discovering Their Great Power of Purifying the Common Air in the Sun-Shine, and of Injuring It in the Shade and at Night (London, 1779), xiii. 
2. Geerdt Magiels, 'Dr Jan IngenHousz, or Why We Don't Know Who Discovered Photosynthesis', paper for the lst Conference of the European Philosophy of Science Association (Madrid, 15-17 November 2007) http://philsci-archive.pitt.edu/3790/1/IngenHousz_EPSA07.pdf [last consulted 14 March 2019]. See also: Norman and Elaine Beale, 'The Life of Dr Jan IngenHousz (1730-1799), Private Counsellor and Personal Physician to Emperor Joseph II of Austria', Journal of Medical Biography 13 (2005), 15-21; 'Jan Ingenhousz: Plant Physiologist,' Chronica botanica 11 (1949), 285-396.

3. Ingenhousz, Experiments, 9-10.

4. Ingenhousz, Experiments, 67-69.

5. Jan Rudolph Deiman and A. Paets van Troostwijk, 'Proefneming omtrent de verbetering der lugt, door middel van de groeij der planten', Vaderlandsche Letteroefeningen (1778): 338-49, 437-46, 482-90, 485. See also Joost Kloek and Wijnand Mijnhardt, Dutch Culture in a European Perspective: 1800, Blueprints for a National Community (London: Palgrave, 2004), 321-22.

6. Verhandelingen van het Provinciaal Utrechtsch Genootschap van Kunsten en Wetenschappen, 1 (1781), 467-68.

7. Clement Archer, Miscellaneous Observations on the Effects of Oxygen on the Animal and Vegetable Systems (Bath, 1798), 79.

8. 'Iets over den invloed van woonplaats of verblijf op de gezondheid', Vaderlandsche Letteroefeningen (1810), 373. See also William Buchan, Domestic Medicine, or a Treatise on the Prevention and Cure of Diseases (Philadelphia: Richard Folwell, 1797), 70.

9. Two simultaneous traditions of respiratory medicine, respiratory anatomy and respiratory chemistry, have been identified by historian Leon Goddlieb in his A History of Respiration (Springfield, IL: Charles Thomas, 1964).

10. Robert Menzies, A Dissertation on Respiration (Edinburgh, 1796), iii.

11. Jerome Gaub also employs the Latin version of his name, Hiëronymus David Gaubius. I here use his name in the vernacular.

12. Herman Boerhaave, Dr. Boerhaave's Academical Lectures on the Theory of Physic, 6 vols (London, 1757), vol. 4, 341, 343.

13. Boerhaave, Lectures, vol. 4, 402 .

14. Boerhaave, Lectures, vol. 6, 205, 210-11.

15. Robert Harrington, A Philosophical and Experimental Enquiry into the First and General Principles of Animal and Vegetable Life (London, $1781), 413$.

16. Hugh Smith, Philosophical Inquiries into the Laws of Animal Life (London, 1780). The British Library catalogue ascribes this book to Hugh Smith the Younger (1735/1736-1789). However, as the Philosophical Inquiries are "founded on the principles delivered in a course of 
philosophical lectures in the beginning of the year 1778', I assume Hugh Smith (d. 1790), who gave very popular lecture courses on the theory and practice of physic (ODNB), authored this publication.

17. Today the distinction between a sign and a symptom is understood in terms of the doctor's or the patient's experience: a sign is considered objective evidence of disease that can be observed by others, most notably the doctor. A symptom refers to the subjective patient experience of disease. By contrast, Boerhaave defined the sign of a disease as 'an appearance perceptible by the senses, from which the physician discovers the true cause of the disease'. A symptom is 'the preternatural appearance in a diseased body, which flows from the distemper as its cause, but is distinguishable from the disease itself' and can become a distemper itself (Boerhaave, Lectures, vol. 4, 1, 113).

18. Virchow, quoted in L. J. Rather, Mind and Body in Eighteenth-Century Medicine. A Study Based on Jerome Gaub's 'De regimine mentis' (London: Wellcome Library, 1965), 23.

19. Hieronymus David Gaubius, The Institutions of Medicinal Pathology by H. D. Gaubius, Translated from the Latin by Charles Erskine (London, 1778), 23-24. My italics.

20. Gaubius, Institutions, 284-85.

21. Gaubius, Institutions, 27 and 30.

22. Gaubius, Institutions, 284 and 146.

23. Rina Knoeff, 'The Body is a Barometer. Dutch Doctors on Healthy Weather and Strong Constitutions', in Lifestyle and Medicine in the Enlightenment: The Six Non-Naturals in the Long Eighteenth Century, ed. by James Kennaway and Rina Knoeff (London: Routledge, 2020), 19-42.

24. Benjamin Rumford, An Essay on Chimney Fire-Places; with Proposals for Improving Them to Save Fuel; to Render Dwelling-Houses More Comfortable and Salubrious, and Effectually to Prevent Chimnies from Smoking (Dublin, 1796), 1.

25. Stephen Hales, A Description of Ventilators: Whereby Great Quantities of Fresh Air May with Ease Be Conveyed into Mines, Goals [sic], Hospitals, Work-Houses and Ships (London, 1743).

26. Simon Schaffer, 'Measuring Virtue. Eudiometry, Enlightenment and Pneumatic Medicine', in The Medical Enlightenment of the Eighteenth Century, ed. by Andrew Cunningham and Andrew Wear (Cambridge: Cambridge University Press, 1990), 281-318. On eudiometry in the Netherlands see also Huib J. Zuidervaart, 'An Eighteenth-Century Medical-Meteorological Society in the Netherlands: An Investigation of Early Organization, Instrumentation and Quantification. Part 2', BJHS 39 (2006), 49-66.

27. Jan Golinski, British Weather and the Climate of Enlightenment (Chicago: University of Chicago Press, 2007), 137-40. 
28. See for instance Iman J. van den Bosch, Over de Ziekten van het Vaderland (Amsterdam, 1794).

29. James Kennaway and Rina Knoeff, "For it is the debilitating fibres that exercise restores": Movement, morality and moderation in EighteenthCentury Medical Advice Literature', in Kennaway and Knoeff, Lifestyle and Medicine in the Enlightenment, 111-38.

30. John Sinclair, The Code of Health and Longevity. Or, a Concise View, of the Principles Calculated for the Preservation of Health, and the Attainment of Life, 2 vols (Edinburgh: A. Constable and Co., 1807), vol. 1, 708.

31. Sinclair, Code of Health, vol. 1, 708; vol. 2, Appendix, 'On Athletic Exercise', 87.

32. George Cheyne, An Essay of Health and Long Life (Bath: G. Strahan, 1724), 49.

33. See for instance Cheyne, Essay of Health, 50.

34. Buchan, Domestic Medicine, 69, 73.

35. Kloek and Mijnhardt, Blueprints, 322-24.

36. Paul Rabbits, Hyde Park. The People's Park (Stroud: Amberley, 2015), introduction.

37. William Cadogan, A Dissertation on the Gout: And All Chronic Diseases, Jointly Considered, as Proceeding from the Same Causes (London, 1772), 94.

38. For convenience I use 'psychosomatics' for the emerging field of 'science of the soul' or zielkunde, the 'new' field where physicians were encouraged to treat the mind as well as the body.

39. Rather, Mind and Body, 17.

40. Gaub in Rather, Mind and Body, 10, 194-195.

41. Gaubius, Institutions, 283.

42. Ernst von Feuchtersleben, quoted in Rather, Mind and Body, 24.

43. Gaub in Rather, Mind and Body, 155.

44. Gaub in Rather, Mind and Body, 162.

45. Gaub in Rather, Mind and Body, 164.

46. Gaubius, Institutions, 289.

47. Gaubius, Institutions, 252. See also Rather, Mind and Body, 58.

48. Uvedale Price, An Essay on the Picturesque (London, 1796), 104. On the importance of fibres in eighteenth-century physiology see Hisao Ishizuka, Fiber, Medicine, and Culture in the British Enlightenment (New York: Palgrave Macmillan, 2016); Tobias Cheung, 'Omnis Fibra Ex Fibra: Fibre Oeconomics in Bonnet's and Diderot's Models of Organic Order', in Early Science and Medicine 15 (2010) 66-104; Alexander Berg, 'Die Lehre von der Faser als Form- und Funktionselement des Organismus. Die Geschichte des biologisch-medizinischen Grundproblems vom kleinsten Bauelement des Körpers bis zur Begründung der Zellenlehre', in Virchows Archiv 309 (1942), 333-460. 
49. Price, Essay on the Picturesque, 105.

50. Lambertus Bicker, Natuur- en geneeskundige verhandeling over de oorzaken, den aart, en de genezing der zenuwziekten (Utrecht, 1793). Presumably Bicker referred to the colour 'Berlin or Prussian blue', invented in 1704 and cheaply available from 1724. See C. Willemijn Fock, ed., Het Nederlandse Interieur in beeld 1600-1900 (Zwolle: Waanders, 2001), 195.

51. Diderot's Essai sur la Peinture, discussed in Nieuwe Algemene konst-en letter-bode 14 (1794), 51-52.

52. George Adams, Verhandeling over het zien (Amsterdam, 1792), 110-11.

53. John Thomson, et al., An Account of the Life, Lectures and Writings of William Cullen, 2 vols (Edinburgh: Blackwood, [1832] 1859), vol. 1, 296-97. Thomson quotes William Cullen, First Lines of the Practice Physic (1784), vol. 2, 363.

54. Frances Gage, Painting as Medicine in Early Modern Rome. Giulio Mancini and the Efficacy of Art (Pennsylvania: Pennsylvania University Press, 2008), 85.

55. Gage, Painting as Medicine, 82-85.

56. Frances Gage, "Chasing "good air" and Viewing Beautiful Perspectives: Painting and Health Preservation in Seventeenth-Century Rome', in Conserving Health in Early Modern Culture. Bodies and Environments in Italy and England, ed. by Sandra Cavallo and Tessa Storey (Manchester: Manchester University Press, 2017), 237-61, 254.

57. Antony Pasquin, Memoirs of the Royal Academicians; Being an Attempt to Improve the National Taste (London, 1796), 20, 121, and 139.

58. Roger Piles, The Principles of Painting (London, 1743), 123.

59. Joshua Reynolds, 'Redevoering', in Algemeen Magazyn van Wetenschap, Konst en Smaak (Amsterdam, 1785), 132 and 138.

60. De Werken van Vondel, 10 vols (Amsterdam: De Maatschappij voor goede en goedkope lectuur, 1927), vol. 9, 300.

61. Rheinvis Feith, quoted in Kloek and Mijnhardt, Blueprints, 510.

62. Ineke Strouken, Tussen plafond en print. Cultuurgeschiedenis van het behang (Utrecht: Nederlands Centrum voor Volkscultuur, 1992).

63. Fock, Het Nederlandse Interieur, 81-82; J. de Loos-Haaxman, 'De behangselfabriek der Vaderlandsche Maatschappij te Hoorn', Nederlands Kunsthistorisch Jaarboek 12 (1961), 149-92, 172.

64. Inge Verslype, Margriet van Eikema Hommes and Annemieke Heuft, 'De oorspronkelijke gedaante van de geschilderde kamer in het Martenahuis te Franeker', in Bulletin KNOB (2017), 101-22, 113. See also C. Willemijn Fock, 'Het interieur in de Republiek 1670-1750: (g)een plaats voor schilderkunst?', in ed. by Ekkehard Mai, Sander Paarlberg, and Gregor J. M. Weber, De kroon op het werk. Hollandse schilderkunst 1670-1750 (Köln: Locher, 2006), 63-86, 70. 
65. Jet Pijzel-Domisse, Het Hollandse poppenhuis. Interieur en huishouden in de $17^{\text {de }}$ en de $18^{\text {de }}$ eeuw (Zwolle: Waanders, 2000), 96.

66. For details on the dollhouse and the painted room see Pijzel-Domisse, Het Hollandse poppenhuis, 247-346.

67. Gage, Painting as Medicine, 49; Fock, Het Nederlandse Interieur, 91, 187.

68. Gage, Painting as Medicine, 81.

\section{Selected Bibliography}

Fock, Willemijn, ed. 2001. Het Nederlandse Interieur in beeld 1600-1900. Zwolle: Waanders.

Gage, Frances. 2008. Painting as Medicine in Early Modern Rome. Giulio Mancini and the Efficacy of Art. Pennsylvania: Pennsylvania University Press.

Golinski, Jan. 2007. British Weather and the Climate of Enlightenment. Chicago: University of Chicago Press.

Ishizuka, Hisao. 2016. Fiber, Medicine, and Culture in the British Enlightenment. New York: Palgrave Macmillan.

Kloek, Joost, and Wijnand Mijnhardt. 2004. Dutch Culture in a European Perspective: 1800, Blueprints for a National Community. London: Palgrave.

Kennaway, James and Rina Knoeff, eds 2020. Lifestyle and Medicine in the Enlightenment: The Six Non-Naturals in the Long Eighteenth Century. London: Routledge.

Rather, L. J. 1965. Mind and Body in Eighteenth-Century Medicine: A Study Based on Jerome Gaub's 'De regimine mentis'. London: Wellcome Library.

Schaffer, Simon. 1990. Measuring Virtue. Eudiometry, Enlightenment and Pneumatic Medicine. In The Medical Enlightenment of the Eighteenth Century, ed. Andrew Cunningham and Andrew Wear. Cambridge: Cambridge University Press.

Vila, Anne C. 1998. Enlightenment and Pathology. Sensibility in the Literature and Medicine of Eighteenth-Century France. Baltimore: Johns Hopkins University Press. 
Open Access This chapter is licensed under the terms of the Creative Commons Attribution 4.0 International License (http://creativecommons.org/licenses/ by $/ 4.0 /$ ), which permits use, sharing, adaptation, distribution and reproduction in any medium or format, as long as you give appropriate credit to the original author(s) and the source, provide a link to the Creative Commons license and indicate if changes were made.

The images or other third party material in this chapter are included in the chapter's Creative Commons license, unless indicated otherwise in a credit line to the material. If material is not included in the chapter's Creative Commons license and your intended use is not permitted by statutory regulation or exceeds the permitted use, you will need to obtain permission directly from the copyright holder.

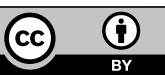

